\title{
Preface: plants in hydrosystems: from functional ecology to weed research
}

\author{
Teresa Ferreira • Matthew T. O'Hare • \\ Krzysztof Szoszkiewicz • Seppo Hellsten
}

Published online: 22 May 2014

(C) The Author(s) 2014. This article is published with open access at Springerlink.com

\section{Introduction}

Aquatic plants are important components of aquatic ecosystems (Chambers et al., 2008). They produce consumable materials that form the basis of trophic networking, they influence the hydrological, geomorphological and chemical environments and they interact in different ways with microbial and animal compartments and ecosystem processes.

The interplay between humans and aquatic environments is often mediated through aquatic plants to both positive and negative ends. The biological traits of those plants and their communities are an essential aid to understanding the role of aquatic vegetation and their ecological interactions across different spatial

Guest editors: M. T. Ferreira, M. O’Hare, K. Szoszkiewicz \& S. Hellsten / Plants in Hydrosystems: From Functional Ecology to Weed Research

T. Ferreira (西)

Agronomy Institute, University of Lisbon, Lisbon,

Portugal

e-mail: terferreira@isa.utl.pt

M. T. O'Hare

Centre for Ecology \& Hydrology (CEH), Edinburgh, UK

K. Szoszkiewicz

Poznan University of Life Sciences, Poznan, Poland

S. Hellsten

Finnish Environment Institute (SYKE), Oulu, Finland and time scales (Capers et al., 2010; Gurnell et al., 2010; Bornette \& Puijalon, 2011). For example, combinations of environmental conditions and traits can lead to invasive processes harmful to human activities and ecosystems (Gordon \& Gantz, 2011). But plants can also be used to mitigate human impacts, such as the use of constructed macrophyte beds for nutrient removal (Xian et al., 2010). A mechanistic understanding of plant-ecosystem interactions, and how they are perturbed by human disturbances, enables the monitoring of the macrophyte communities and water bodies where they exist, and ultimately provides the clues and tools to protect and rehabilitate aquatic environments and plant populations (Lumbreras et al., 2013; Aguiar et al., 2014). The present volume is a contribution to such understanding of ecological interactions and its applications to freshwater management.

\section{The present issue}

This special issue of Hydrobiologia comprises the refereed proceedings of the International Symposium on Aquatic Plants held in Poznan, Poland during 27-31 August 2012. The symposium has hosted the 13th International Symposium on Aquatic Plants of the European Weed Research Society, and the 2nd International Workshop of the Working Group on Macrophytes of the International Limnological Society. The present volume includes 24 papers, divided 
into four topics, (1) Vegetation and Ecological interactions, (2) Biology and Taxonomy, (3) Bioindication and Biomonitoring and (4) Vegetation Management and Restoration.

The symposium was attended by 140 participants from 24 different countries, resulting in 67 presentations and 78 posters. These countries included Belgium, Brasil, Bulgaria, Canada, Czech Republic, Egypt, Estonia, France, Finland, Germany, Hungary, Italy, Japan, Latvia, the Netherlands, New Zealand, Norway, Poland, Portugal, Slovenia, Spain, Sweden, Switzerland and United Kingdom. The Symposium' prime theme was 'Plants in Hydrosystems: from Functional Ecology to Weed Research'.

\section{History}

In 1964 the European Weed Research Council (EWRC), later called the European Weed Research Society (1975), started a series of international symposia on aquatic weeds through its Working Group (WG) on Aquatic Weeds. Up to 2002, these symposia were held with a 3-4 year interval in: La Rochelle, France (1964), Oldenburg, Germany (1967), Oxford, UK (1971), Vienna, Austria (1974), Amsterdam, The Netherlands (1978), Novi Sad, Yugoslavia (1982), Loughborough, UK (1986), Uppsala, Sweden (1990), Dublin, Ireland (1994), Lisbon, Portugal (1998) and Moliets et Maâ, France (2002). During two decades, the focus of these Symposia was the nuisance plants (so-called 'weeds' in the sense of being harmful to human activities, mainly agriculture), their biology and forms of control. Progressively, other aspects took dominance, such as interactions with other components of the ecosystem, non-native invasion processes, plant conservation and the monitoring of water quality. In general, a humandominated view gave way to an ecosystem-based perspective, and management practice driven by ecosystem functioning.

The importance of technical aspects and casestudies was also progressively complemented, and later overrun by theoretical aspects and concepts of functioning, at individual, population and ecosystem levels, and these were used to predict management and ecosystem restoration outcomes. From the 9th Symposium onward (Dublin, 1994), the authors were also invited to elaborate their contributions into full papers to be published in a special issue of the journal Hydrobiologia (Caffrey et al., 1996; Caffrey et al., 1999; Caffrey et al., 2006). After the 11th International Symposium on Aquatic Weeds in Moliets et Maâ, in 2002, the WG on Aquatic Weeds ceased to exist independently within the EWRS. Eventually the Finnish Environment Institute (SYKE) took the lead in organising the follow-up 12th International Symposium on Aquatic Weeds in Jyväskylä in 2009 in cooperation with The International Society of Limnology (SIL), by means of their Working Groups on Aquatic Macrophytes and Wetlands (Pieterse et al. 2010). The success of the Jyväskylä Symposium enabled the continuity of the series, with the 13th EWRS International Symposium on Aquatic Plants. The Aquatic Symposium series, now with a proud tradition of half a century (1964-2014), will be next organised in Edinburgh, United Kingdom, in 2015, and further in New Zealand in 2019.

\section{SYMPOSIUM SPONSORS}

Wojewódzki Fundusz Ochrony Srodowiska i Gospodarki Wodnej w Poznaniu

Zespół Parków Krajobrazowych Województwa Wielkoposkiego

PROTE Technologie dla Środowiska Sp. z O.O.

Sartorius Sedim Biotech

Volkswagen Polska

\section{ORGANISING INSTITUTIONS}

European Weed Research Society (EWRS)

International Society on Limnology (SIL) - Working Group on Macrophytes

Polish Hydrobiological Society (PHA)

Poznań University of Life Sciences

Landscape Park Complex of the Wielkopolska Region

\section{SCIENTIFIC COMMITTEE}

Maria Teresa Ferreira - Chair (Portugal), Takashi Asaeda (Japan), Annette Baatrup-Pedersen (Denmark), Liesbeth Bakker (Netherlands), Christian Bohren (Switzerland), Patricia A. Chambers (Canada), John Clayton (New Zealand), Carin Van Ginkel (South Africa), Ryszard Gołdyn (Poland)

Jacques Haury (France), Seppo Hellsten (Finland), Georg A. Janauer (Austria), Matthew O'Hare (UK) Jonathan Newman (UK), Mariusz Pełechaty (Poland), Sergi Sabater (Spain), Krzysztof Szoszkiewicz (Poland), Ludwig Triest (Belgium), Nigel Wilby (UK) 


\section{ORGANISING COMMITTEE}

Krzysztof Szoszkiewicz - Chair, Wojciech Antkowiak, Leszek Bednorz, Anna Budka, Sofia Celewicz-Gołdyn, Maciej Gąbka, Daniel Gebler, Ryszard Gołdyn, Sławomir Janyszek, Szymon Jusik, Tomasz Kałuża, Dariusz Kayzer, Agnieszka Ławniczak, Maria Morozowska, Mariusz Pełechaty, Andrzej Pukacz, Marta Szwabińska, Justyna Urbaniak, Janina Zbierska, Tomasz Zgoła

Open Access This article is distributed under the terms of the Creative Commons Attribution License which permits any use, distribution, and reproduction in any medium, provided the original author(s) and the source are credited.

\section{References}

Aguiar, F. C., P. Segurado, G. Urbanič, J. Cambra, C. Chauvin, S. Ciadamidaro, J. Ferreira, G. Dörflinger, M. Germ, P. Manolaki, M. R. Minciardi, A. Munné, E. Papastergiadou \& M. T. Ferreira, 2014. Comparability of river quality assessment using macrophytes: a multi-step procedure to overcome biogeographical differences. Science of Total Environment 476-477: 757-767.

Bornette, G. \& S. Puijalon, 2011. Response of aquatic plants to abiotic factors: a review. Aquatic Sciences 73: 1-14.

Caffrey, J. M., P. R. F. Barrett, K. J. Murphy \& P. M. Wade (Guest Editors), 1996. Management and ecology of freshwater plants. Hydrobiologia 340: 1-354.

Caffrey, J. M., P. R. F. Barrett, M. T. Ferreira, I. S. Moreira, K. J. Murphy \& P. M. Wade (Guest Editors), 1999. Biology, ecology and management of aquatic plants. Hydrobiologia 415: 1-339.

Caffrey, J. M., A. Dutartre, J. Haury, K. J. Murphy \& P. M. Wade (Guest Editors), 2006. Macrophytes in aquatic ecosystems: from biology to management. Hydrobiologia 570: $1-263$.

Capers, R. S., R. Selsky \& G. J. Bugbee, 2010. The relative importance of local conditions and regional processes in structuring aquatic plant communities. Freshwater Biology 55: 952-966.

Chambers, P. A., P. Lacoul, K. Murphy \& S. Thomaz, 2008. Global diversity of aquatic macrophytes in freshwater. Hydrobiologia 595: 9-26.

Gordon, D. R. \& C. A. Gantz, 2011. Risk assessment for invasiveness differs from aquatic to terrestrial plant species. Biological Invasions 13: 1829-1842.

Gurnell, A. M., J. M. O’Hare, M. J. Dunbar \& P. M. Scarlett, 2010. An exploration of associations between assemblages of aquatic plant morphotypes and channel morphological properties within British rivers. Geomorphology 116: 135-144.

Lumbreras, A., C. Pardo \& J. A. Molina, 2013. Bioindicator role of aquatic Ranunculus in Mediterranean freshwater habitats. Aquatic Conservation: Marine \& Freshwater Ecosystems 23: 582-593.

Pieterse, A. H., S. Hellsten, J. Newman, J. Caffrey, F. Ecke, T. Ferreira, B. Gopal, J. Haury, G. Janauer, T. Kairesalo, A. Kanninen, K. Karttunen, J. Sarvala, K. Szoszkiewicz, H. Toivonen, L. Triest, P. Uotila \& N. Willby, 2010. Aquatic invasions and relation to environmental changes. Hydrobiologia 656: 1-267.

Xian, Q., L. Hu, H. Chen, Z. Chang \& H. Zou, 2010. Removal of nutrients and veterinary antibiotics from swin wastewater by a constructed macrophyte floating bed system. Journal of Environmental Management 91: 2657-2661. 